INDONESIAN HEALTH ISSUE

\title{
HUBUNGAN STATUS GIZI IBU NIFAS DENGAN PENYEMBUHAN LUKA PERINEUM Ribur Sinaga ${ }^{1}$, Kamelia Sinaga ${ }^{2}$,Parningotan Simanjuntak ${ }^{3}$, Nopalina S Damanik $^{4}$ \\ ${ }^{1-4}$ STIKes Mitra Husada Medan Email korespondensi: ribursinaga@gmail.com No HP: 081263605678
}

\section{ARTICLE INFO \\ Received : \\ 12 Januari 2022 \\ Accepted : \\ 14 Februari 2022 \\ Published : \\ 16 Februari 2022}

\section{Kata Kunci: \\ Status Gizi \\ Ibu Nifas \\ Luka Perineum}

\section{Keywords:}

Nutriional Status

Pospartum

Perineal Ruptur

\begin{abstract}
ABSTRAK
Latar Belakang: Kejadian ruptur perineum pada ibu bersalin di dunia pada tahun 2015 terdapat 2,7 juta kasus, dimana angka ini diperkirakan akan mencapai 6,3 juta pada tahun 2050.Tujuan: untuk mengetahui hubungan status gizi dan pemulihan luka perineum. Metode:Penelitian ini menggunakan desain cross sectional study. Penelitian dilakukan di Puskesmas Bagan Asahan Kec. Bagan Asahan Kab. Asahan dengan jumlah sampel 15 orang dan diambil secara Total Sampling. Analisis data menggunakan uji Cgi-square. Hasil:Hubungan antara vaiabel dikatakan bermakna jika p-value < 0,05.Dengan menggunakan metode pengukuran LILA dan IMT dperoleh hasil hampir semua ibu nifas memiliki status gizi yang baik $(87,6 \%)$ dan luka perineumnya mengalami pemulihan. Terdapat hubungan antara status gizi ibu nifas dengan pemulihan luka perineum $(p<0,05)$. Terdapat hubungan antara hubungan status gizi dan pemulihan luka perineum. Saran:Diharapkan tenaga kesehatan dapat memberikan pendidikan kesehatan yang lebih banyak kepada ibu nifas mengenai pemenuhan zat gizi selama masa nifas agar mempercepat pemulihan status gizi.
\end{abstract}

\begin{abstract}
Background: The incidence of perineal rupture in childbirth in the world in 2015 there were 2.7 million cases, where this figure is estimated to reach 6.3 million in 2050. Objective: To determine the relationship between nutritional status and perineal wound recovery. Methods: This study used a cross sectional study design. The research was conducted at the Bagan Asahan Health Center, Kec. District Asahan Chart. Asahan with a sample of 15 people and taken by Total Sampling. Data analysis using Cgi-square test. Result: The relationship between variables is said to be significant if the p-value $<0.05$. By using the LILA and BMI measurement methods, almost all postpartum mothers have good nutritional status (87.6\%) and their perineal wounds have recovered. There is a relationship between the nutritional status of postpartum mothers with perineal wound recovery $(p<0.05)$. There is a relationship between nutritional status and perineal wound recovery. Suggestion: It is hoped that health workers can provide more health education to postpartum mothers regarding the fulfillment of nutrients during the postpartum period in order to accelerate the recovery of nutritional status.
\end{abstract}




\section{PENDAHULUAN}

Persalinan normal menurut WHO (2010) adalah persalinan yang dimulai secara spontan, beresiko rendah pada awal persalinan, berisiko rendah pada awal persalinan dan tetap demikian selama proses persalinan, bayi lahir secara spontan dalam presentasi belakang kepala pada usia kehamilan 37-42 minggu lengkap dan setelah persalinan ibu maupun bayi berada dalam kondisi sehat. Menurut Rohani yang dikutip Oktarina (2016) persalinan merupakan proses yang ditandai dengan adanya kontraksi rahim (uterus) yang kemudian menyebabkan terjadinya dilatasi progresif dari serviks, kelahiran bayi dan kelahiran plasenta dan proses tersebut merupakan proses alamiah (Oktarina, 2016)

Menurut Puji (2019) yang mengutip pendapat Mochtar proses persalinan sering menimbulkan robekan pada jalan lahir, robekan tersebut terjadi hampir pada semua persalinan pertama kali dan tidak jarang juga pada persalinan berikutnya. Robekan jalan lahir adalah perdarahan dalam keadaan dimana plasenta telah lahir lengkap dan kontraksi rahim baik, dapat dipastikan bahwa perdarahan tersebut berasal dari perlukaan jalan lahir (Cuningham, 2012)

Menurut Winkjosatro dalam Nur \& Ummah (2019) robekan pada jalan lahir dapat terjadi spontan maupun karena disengaja(episiotomi) yaitu luka perineum yang terjadi karena dilakukan pengguntingan atau perobekan pada perineum (Wiknjosastro, 2009).

Menurut Oktavia (2017), kejadian ruptur perineum pada ibu bersalin di dunia pada tahun 2015 terdapat 2,7 juta kasus, dimana angka ini diperkirakan akan mencapai 6,3 juta pada tahun 2050. Di benua Asia sendiri hampir $50 \%$ ibu bersalinmengalami ruptur perineum. Sedangkan di Indonesia sendiri menurut Sofiyani dalam Oktavia (2017) prevalensi ibu bersalin yang mengalami ruptur perineum di Indonesia $52 \%$ dikarenakan persalinan dengan bayi berat lahir cukup atau lebih.

Ruptur perineum pada ibu dapat mengakibatkan terjadinya luka infeksi yang dapat merambat pada saluran kandung kemih ataupun jalan lahir hingga dapat menimbulkan komplikasi.Selain itu perdarahan juga dapat terjadi karena pembuluh darah yang tidak menutup dengan sempurna.Penanganan komplikasi yang lambat dapat menyebabkan terjadinya kematian ibu nifas mengingat kondisi ibu nifas yang masih lemah (Putri, 2017).Kondisi ini menjadi salah satu penyebab kematian ibu di Indonesia. Menurut Direktorat Kesehatan Masyarakat Kemenkes (2019) saat ini penyebab kematian ibu akibat gangguan hipertensi sebanyak 33,07\%, perdarahan obstetric $27,03 \%$, komplikasi non obstetric $15,7 \%$, komplikasi obstetrik lainnya $12,04 \%$, infeksi $6,06 \%$ dan penyebab lainnya $4,81 \%$.

Upaya yang dapat dilakukan untuk mencegah terjadinya resiko infeksi adalah dengan melakukan perawatan luka perineum.Perawatan luka perineum yang dilakukan dengan baik dapat mempercepat penyembuhan luka perineum (Sukmarani, 2018).

Putri (2017) mengatakan bahwa proses penyembuhan luka sangat berhubungan dengan usia, berat badan, status gizi, dehidrasi, aliran darah yang adekuat ke area luka dan status imunologinya. Sedangkan faktor-faktor yang memperlambat proses penyembuhan luka menurut Putu adalah status nutrisi yang tidak tercukupi, kebiasaan merokok, penambahan usia, peningkatan kortikosteroid akibat stress, gangguan oksigenasi dapat mengganggu sintesiskolagen dan menghambat epitelisasi dan infeksi (Putri, 2017)

Menurut Taylor dalam Putri (2017) status gizi atau nutrisi ibu yang kurang baik akan berpotensi menimbulkan infeksi akibat luka. Malnutrisi secara umum dapat 
mengakibatkan berkurangnya kekuatan luka, meningkatnya dehisensi luka, meningkatnya kerentanan terhadap infeksi dan parut dengan kualitas yang buruk. Status gizi seimbang ibu nifas sangat berpengaruh terhadap proses penyembuhan luka. Retna dalam Khodir (2017) mengatakan bahwa status gizi merupakan keadaan tubuh sebagai akibat konsumsi makanan dan penggunaan zat-zat gizi. Zat ini berfungsi untuk membantu proses metabolisme, pemeliharaan dan pembentukan jaringan baru. Selain itu, gizi yang seimbang juga merupakan zat yang diperlukan oleh tubuh untuk keperluan metabolismenya. Kebutuhan gizi pada masa nifas terutama bila menyusui akan meningkat $25 \%$ karena berguna untuk proses kesembuhan karena sehabis melahirkan dan untuk memproduksi air susu yang cukup untuk menyehatkan bayi. Semua itu akan meningkat tiga kali dari kebutuhan biasa (Putri, 2017).

Putri (2017) dalam penelitiannya menemukan bahwa terdapat hubungan antara status gizi dengan kesembuhan luka perineum pada ibu nifas di RS Dewi Sartika Kota Kendari. Dalam penelitiannya yang menemukan bahwa pengetahuan ibu nifas yang baik tentang makanan gizi seimbang dapat mempercepat proses penyembuhan luka perineum (Putri, 2017)

Status gizi seimbang ibu nifas sangat berpengaruh terhadap proses penyembuhan luka. Status gizi merupakan keadaan tubuh sebagai akibat konsumsi makanan dan penggunaan zat - zat gizi. Zat gizi ini berfungsi untuk membantu proses metabolisme, pemeliharaan dan pembentukan jaringan baru. Selain itu, giziyang seimbang juga merupakan zat yang diperlukan oleh tubuh untuk keperluan metabolismenya. Kebutuhan gizi pada masa nifas terutama bila menyusui akan meningkat $25 \%$, karena berguna untuk proses kesembuhan karena sehabis melahirkan dan untuk memproduksi air susu yang cukup untuk menyehatkan bayi. Semua itu akan meningkat tiga kali dari kebutuhan biasa

Menurut survey awal yang dilakukan di wilayah kerja Puskesmas Bagan Asahan Kec. Tanjung Balai Kab. Asahan terhadap 10 ibu yang mengalami Luka perineum 4 orang ibu mengalami penyembuhan luka perineum yang lebih cepat karena mereka memiliki gizi yang baik sedangkan 6 ibu yang lain mengalami penyembuhan yang lebih lambat karena mereka memiliki status gizi yang kurang.

Berdasarkan kenyataan bahwa luka perineum dapat menjadi faktor predisposisi terjadinya infeksi pada masa nifas maka peneliti tertarik untuk mengetahui status gizi ibu nifas dan hubungannya dengan penyembuhan luka perineum di Wilayah Kerja Puskesmas Bagan Asahan Kec. Tanjung Balai Kab. Asahan Tahun 2021

\section{METODE PENELITIAN}

Penelitian ini adalah penelitian Analitik Deskriptif dan menggunakan desain studi Cross Sectional yang bertujuan untuk melihat suatu gambaran fenomena kesehatan masyarakat pada satu titik point waktu tertentu. Penelitian ini merupakan studi deskriptif analitik untuk mengetahui hubungan status gizi ibu nifas dengan penyembuhan luka perineum di wilayah kerja Puskesmas Bagan Asahan Kec. Tanjung Balai Kab. Asahan Tahun 2021

Teknik aksidental sampling dipilih sebagai teknik pengambilan sampel dalam penelitian ini. Teknik Total Sampling adalah merupakan teknik penentuan yang dimana Seluruh populasi di jadikan sampel(Anwar, 2017)

Dalam penelitian ini peneliti menggunakan jenis data primer yaitu data yang diambil/ diperoleh langsung oleh peneliti dengan menggunakan kuesioner. Kuesioner merupakan teknik pengumpulan data yang dilakukan dengan cara memberi seperangkat pertanyaan tertulis kepada responden untuk 
dijawabnya(Sugiyono, 2011).

\section{HASIL PENELITIAN}

\section{a. Analisis Univariat}

Analisis univariat merupakan analisis yang dilakukan untuk memperoleh gambaran setiap variabel, distribusi frekueni berbagai variabel yang diteliti baik variabel terikat maupun variabel beba yang kemudian ditampilkan dalam bentuk distribusi frekuensi.Analisis univariat pada penelitian ini, yaitu karakteristik responden, status gizi dan penyembuhan luka perineum. Hasil analisis univariat sebagai berikut:

Tabel 1.Distribusi Frekuensi Status Gizi Ibu Nifas Berdasarkan Ukuran LILA di Wilayah Kerja Puskesmas Bagan Asahan Tahun 2021

\begin{tabular}{ccc}
\hline Status Gizi lbu & Frekuensi $(\mathbf{n})$ & Persentase $\mathbf{( \% )}$ \\
\hline Baik & 13 & 86,7 \\
Kurang & 2 & 13,3 \\
\hline Total & $\mathbf{1 5}$ & $\mathbf{1 0 0}$
\end{tabular}

Hasil pengukuran ini juga sama dengan hasil yang diperoleh dengan metode pengukuran LILA pada ibu nifas. Hasil yang diperoleh status gizi ibu nifas dalam status baik sebnayak 13 responden $(86,7 \%)$ dan status kurang sebanyak 2 responden $(13,3)$.

\section{b. Analisis Bivariat}

Analisis bivariat yang digunakan pada penelitian ini, yaitu Hasil analisis Chisquare diperoleh hasil bahwa ada hubungan antara status gizi ibu nifas dengan penyembuhan luka perineum.

Tabel 2.Hubungan Status Gizi Ibu Nifas Dengan Penyembuhan Luka Perineum di Wilayah Kerja Puskesmas Bagan Asahan Tahun 2021

Dengan Metode LILA

\begin{tabular}{|c|c|c|c|c|c|}
\hline \multirow[t]{3}{*}{ Status gizi } & \multicolumn{4}{|c|}{ Penyembuhan Luka Perineum } & \multirow[t]{3}{*}{$P$} \\
\hline & \multicolumn{2}{|c|}{ Sembuh } & \multicolumn{2}{|c|}{ Belum Sembuh } & \\
\hline & $\mathrm{N}$ & $\%$ & $\mathrm{~N}$ & $\%$ & \\
\hline Baik & 13 & 100 & 0 & 0 & \\
\hline Kurang & 0 & 0 & 2 & 100 & 0,00 \\
\hline
\end{tabular}

Setelah dilakukan analisis data tentang hubungan status gizi ibu nifas dengan penyembuhan luka perineum maka diperoleh hail penelitian bahwa dari 13 ibu nifas yang luka perineumnya sembuh semua status gizinya baik sebanyak 13 ibu (100\%) sedangkan dari 2 ibu nifas yang luka perineumnya belum sembuh semua status gizinya kurang sebanyak 2 ibu (100\%). Hasil analisis Chi-square diperoleh hasil bahwa ada hubungan antara status gizi ibu nifas dengan penyembuhan luka perineum $(p=0,000)$.

Tabel 3.Hubungan Status Gizi Ibu Nifas Dengan Penyembuhan Luka Perineum di Wilayah Kerja Puskesmas Bagan Asahan Tahun 2021

Dengan Metode IMT

\begin{tabular}{cccccc}
\hline Status gizi & \multicolumn{4}{c}{ Penyembuhan Luka Perineum } & $P$ \\
& $\begin{array}{c}\text { Sembuh } \\
\text { Nelum Sembuh }\end{array}$ & \\
& $\mathrm{N}$ & $\%$ & $\mathrm{~N}$ & $\%$ & \\
\hline Normal & 13 & 100 & 0 & 0 & 0,000 \\
\hline
\end{tabular}


$\begin{array}{lllll}\text { Tidak Normal } & 0 & 0 & 2 & 100\end{array}$

Hasil pengukuran ini juga sama dengan hasil yang diperoleh dengan metode pengukuran Indeks Massa Tubuh (IMT) pada ibu nifas. Hal ini dapat dilihat dari tabel di bawah ini. Hasil analisis Chi-square diperoleh hasil bahwa ada hubungan antara status gizi ibu nifas dengan penyembuhan luka perineum $(p=0,000)$. Kesimpulan yang dapatdiperoleh adalah ada hubungan antara status gizi ibu dengan keembuhan luka perineum. Semaikin baik status gizi ibu nifas maka semakin cepat kesembuhan luka perineum

Penelitian tentang adakah hubungan antara status gizi ibu nifas dalam penyembuhan luka perineum di wilayah kerja Puskesmas Bagan Asahan Kec.Tanjung Balai Kab.Asahan Tahun 2021. Hasil penelitian menyatakan bahwa ada antara hubungan satus gizi ibu nifas dengan penyembuhan luka perineum.

Penelitian yang sama yang dilakukan oleh (Rahmawati, 2014) di Kediri juga menemukan bahwa semua ibu nifas yang kebutuhan gizinya terpenuhi mempunyai luka perineum yang sembuh. Kebutuhan gizi pada masa nifas sebaiknya mengandung tinggi kalori.Kecukupan gizi selama 6 bulan pertama masa laktasi 330 kkal lebih tinggi daripada saat tidak hamil.Beberapa zat gizi, baik zat gizi makro maupun mikro berperan penting dalam pemulihan luka. Penurunan cadangan protein dalam tubuh pada kasus gizi kurang atau buruk menyebabkan penurunan fungsi sel $\mathrm{T}$, penurunan aktivitas fagositik dan penurunan level antibodi sehingga memicu terjadinya infeksi. Kekurangan protein juga dapat menyebabkan kegagalan sintesi kolagen dan penurunan kekuatan kuli.Karbohidrat dan lemak juga dibutuhkan dalam sintesis kolagen. Defisiensi asam lemak bebas dapat menyebabkan gagalnya pemulihan luka karena fosfolipid merupakan bahan dasar pembentukan membran sedangkan prostaglandin yang disintesis oleh asam lemak bebas berperan dalam metabolisme sel dan inflamasi (Walyani, 2015)

Menurut (Rahmawati, 2014)vitamin C dan vitamin A juga berperan dalam sintesis kolagen. Defisiensi vitamin C akan menyebabkan kerentanan terjadinya infeksi. Zat gizi mikro seperti zink, zat besi dan magnesium juga berperan dalam pemulihan luka. Defisiensi zink akan menyebabkan penurunan proliferasfibroblas dan sintesis kolagen. Peran magnesium dalam pemulihan luka adalah sebagai kofaktor enzim dalam sintesis kolagen. Zat gizi mikro lainnya yang berperan penyembuhan luka antara lain vitamin $B$, vitamin $E$, vitamin $K$, kalsium dan selenium. Air juga berperan dalam mendukung terjadinya proliferasi sel. Dehidrasi menyebabkan pengerasan epidermis yang akan memperlama penyembuhan luka (Khodir, A.J., Putri, 2016).

Penelitian yang dilakukan (Putri, 2017) di RS Dewi Sartika Kota Kendari juga menemukan hal yang sama dengan penelitian ini dimana Dewi menemukan bahwa status gizi mempengaruhi kesembuhan luka perineum. Dari hasil analisis data ditemukan bahwa dari 51 ibu nifas yang luka perineumnya sembuh sebagian besar status gizinya baik sebanyak 43 ibu $(66,2 \%)$.

Luka perineum adalah robekan jaringan antara pembukaan vagina dan rektum. Luka jahitan perineum bisa disebabkan oleh rusaknya jaringan secara alamiah karena proses desakan kepala janin atau bahu pada saat proses persalinan maupun tindakan episiotomi .Klasifikasi luka perineum menurut Saifuddin (2012) terbagi dua bagian yaitu luka perineum spontan dan yang disengaja (episiotomi).Pada penelitian ini luka perineum disebabkan oleh luka perineum spontan.

Dampak dari terjadinya luka perineum pada ibu diantaranya terjadinya infeksi pada luka jahitan, dan dapat merambta pada saluran kandung kemih ataupun pada 
jalan lahir sehingga dapat berakibat pada munculnya komplikasi infeksi kandung kemih maupun infeksi pada jalan lahir. Selain itu juga dapat terjadi perdarahan karena terbukanya pembuluh darah yang tidak menutup sempurnaPenanganan komplikasi yang lambat dapat menyebabkan terjadinya kematian ibu postpartum mengingat kondisi ibu postpartum masih lemah (Manuaba, 2012)

Salah satu upaya dalam rangka menurunkan angka kejadian infeksi akibat luka perineum (Saifuddin, 2014). Perawatan yang tidak benar dapat menyebabkan infeksi dan memperlambat penyembuhan, karena perawatan yang salah dapat mengakibatkan kapiler darah baru rusak dan mengalami perdarahan, menyatakan bahwa penyembuhan luka perineum dapat dipengaruhi oleh nutrisi yang adekuat, kebersihan, istirahat, posisi, umur, penanganan jaringan, hemoragi, hopvolemia, edema, defisit oksigen, penumpukan drainase, medikasi, overaktifitas, gangguan sistemik, status imunosupresi, stres luka. Pernyataan yang serupa oleh Johnson \& Taylor (2015) bahwa faktor yang dapat mempengaruhi penyembuhan luka perineum diantaranya status nutrisi, merokok, penambahan usia, obesitas, diabetes mellitus (DM), kortikosteroid, obat-obatan, ganguan oksigenasi, infeksi dan stress luka.

Setiap luka tentunya berisiko mengalami infeksi, apalagi jika status gizi atau nutrisi ibu kurang baik.Malnutrisi secara umum dapat mengakibatkan berkurangnya kekuatan luka, meningkatnya dehisensi luka, meningkatnya kerentanan terhadap infeksi dan parut dengan kualitas yang buruk (Taylor, 2014). Faktor gizi terutama protein akan sangat mempengaruhi terhadap proses penyembuhan luka perineum karena penggantian jaringan sangat membutuhkan protein (Rukiyah, 2014).

Menurut Boyle dalam (Putri, 2017)waktu penyembuhan luka dipengaruhi oleh perfusi jaringan dan oksigen, merokok, gangguan hati, stress nutrisi, infeksi, asuhan kurang optimal, obesitas, karakteristik ibubersalin, kondisi perlukaan dan perawatannya.

Status gizi merupakan keadaan tubuh yang diakibatkan oleh keseimbangan antara asupan zat gizi dengan kebutuhan.Keseimbangan tersebut dapat dilihat dari pertumbuhan yaitu berat badan dan tinggi badan.Peninjauan peran berbagai nutrien khususnya dalam mengidentifikasi pengaruh nutrisi dalam penyembuhan luka perineum yang efisien setelah melahirkan. Wanita yang baru melahirkan tidak dapat dihindari mengalami pola tidur yang kurang, nutrisi yang tidak adekuat dan stress psikologis(Putri, 2017).

Menurut peneliti hasil penelitian ini menunjukkan bahwa pengukuran LILA dan IMT merupakan metode yang dapat digunakan untuk mengukur status gizi bagi ibu nifas. Namun perlu diperhatikan cara pengukuran LILA dan IMT tersebut sehingga tidak menimbulkan bias terhadap hasil penelitian khususnya dalam pengukuran IMT ibu nifas.

Berdasarkan hasil penelitian ini, peneliti juga menyimpulkan bahwa penyembuhan luka perineum pada ibu nifas salah satunya dipengaruhi oleh status gizi ibu nifas sendiri. Pengukuran status gizi dengan metode LILA dan IMT dalam penelitian ini menunjukkan bahwa ibu-ibu nifas yang memiliki LILA $>23,5 \mathrm{~cm}$ dan IMT yang normal luka perineumnya lebih cepat sembuh yaitu antara 3-5 hari. Sedangkan ibu nifas yang pengukuran LILA nya di bawah normal dan IMT nya tidak normal menunjukkan luka perineum yang sembuh lebih dari 5 hari. 


\section{SIMPULAN DAN SARAN}

\section{SIMPULAN}

Dalam penelitian dari 15 orang ibu yang menjadi responden ditemukan hanya 2 orang ibu yang memiliki status gizi kurang baik. Dan dalam hal ini kedua orang ibu ini merupakan ibu dengan kategori LILA $<23,5$ dan IMT $<17$. Dengan kata lain 2 orang ibu nifas dengan kondisi tubuh kurus bukan obesitasPeneliti menyimpulkan bahwa gizi yang baik dapat mempercepat penyembuhan luka perineum selain perawatan luka perineum yang benar.

Berdasarkan hasil analisa data dengan menggunakan chi-square dan pembahasan yang telah dilakukan oleh peneliti tentang dapat disimpulkan bahwa:

Mayoritas atau $13 \mathrm{ibu}(86,7 \%)$ luka perineum pada ibu nifas di wilayah kerja Pukesmas Bagan Asahan telah sembuh dengan baik. Hampir semua $(86,7 \%)$ ibu nifas di wilayah kerja Puskesmas Bagan Asahan memiliki status gizi yang baik.. Ada hubungan antara status gizi ibu dengan kesembuhan luka perineum $(p=0,000)$

\section{SARAN}

Saran untuk lbu nifas khususnya kepada ibu yang mengalami luka perineum diharapkan selalu memperhatikan konsumsi asupan gizinya selama masa nifas sehingga mempercepat proses penyembuhan luka perineum

\section{DAFTAR PUSTAKA}

Anwar, H. (2017). Teknik Sampling dalam Penelitian.

Cuningham, F. . (2012). Obstetri Williams. EGC.

Khodir, A.J., Putri, M. \& A. L. . (2016). Hubungan Pengetahuan Ibu Nifas tentang Makanan Gizi Seimbang Dengan Penyembuhan Luka Perineum. Jurnal Endurance., 2, 1.

Manuaba, I. G. . (2012). Gawat Darurat Obstetri Ginekologi \& Obstetri-Ginekologi Sosial untuk Profesi Bidan. EGC.

Oktarina, M. (2016). Buku Ajar Asuhan Kebidanan Persalinan dan Bayi Baru Lahir. Penerbit Deepublish.

Putri, S. T. (2017). Hubungan Status Gizi Ibu Nifas dan Budaya Makanan pantangan Masa Nifas Dengan Penyembuhan Luka perineum di RS Dewi Sartika Kota Kendari Tahun 2017. Politeknik Kesehatan Kendari.

Rahmawati, E. \& T. (2014). Hubungan Pemenuhan Gizi Ibu Nifas Dengan Pemulihan Luka Perineum. Jurnal Wiyata, 2, 1.

Saifuddin, B. . (2014). Ilmu kebidanan. PT. Bina Pustaka Sarwono Prawirohardjo.

Sugiyono. (2011). Metode Penelitian Kuantitatif Kualitatif dan $R \& D$. Alfabeta.

Walyani, D. (2015). Asuhan Kebidanan Masa nIfas \& Menyusui. PT. Pustaka Baru.

Wiknjosastro, H. (2009). Ilmu Kebidanan. Yayasan Bina Pustaka Sarwono Prawirohardjo. 